\title{
Integrated Effect of Rhizobium Inoculation and Phosphorus Application on Tissue Content, Symbiotic and Phosphorus use Efficiency in Soybean Production
}

\author{
Mulambula. $\mathrm{S}^{1}$, Gathungu G. $\mathrm{K}^{2}$, Ndukhu H.O ${ }^{3}$, Ogolla F.O ${ }^{4}$
}

\author{
${ }^{1}$ Department of Plant Sciences Chuka University, Kenya \\ Email:siomulambula@yahoo.com \\ ${ }^{2}$ Department of Plant Sciences Chuka University, Kenya \\ Email:gkgathungu@yahoo.com \\ ${ }^{3}$ Department of Plant Sciences Chuka University, Kenya \\ Email:hndukhu@gmail.com \\ ${ }^{4}$ Department of Biological Sciences, Chuka University, Kenya \\ Email:ogolla.fredy@gmail.com
}

\begin{abstract}
Soybean (Glycine max) is an important legume crop that is cultivated all over the world as livestock feed, food for human consumption, soil fertility improvement and industrial products such as candles and paints. However, Nitrogen $(N)$ and phosphorus $(P)$ nutrient have been attributed to the decline in soybean yields. Furthermore, scanty information is documented on P-efficient soybean genotypes, which are a sustainable $P$ management strategy for enhancing symbiotic efficiency (SEF) and phosphorus use efficiency (PUE). As a solution, field experiment was conducted at Chuka University farm to evaluate the integration effect of rhizobium inoculation $(R)$ and P on tissue nutrient content, SEF and PUE in soybean production in Meru South Sub County. Two cultivations (Trial I and II) were done in 2018. Treatments included; three rates of $R\left(0,100\right.$ and $\left.200 \mathrm{~g} \mathrm{ha}{ }^{-1}\right)$, three rates of $P\left(0,20\right.$ and $\left.30 \mathrm{~kg}^{-} \mathrm{ha}^{-1}\right)$, either applied alone or integrated and soybean genotypes (SB19 and SB24). Both Trials were laid out in a randomized complete block design in split-split plot arrangement with each treatment replicated thrice. Genotypes were assigned main plot, $R$ subplots and $P$ in sub-subplots. Data collected was subjected to analysis of variance using the Scientific Analysis System SAS and significantly different means separated using Tukey test at ( $p \leq 0.05)$. The results showed significant difference in $N$ and $P$ tissue content, SEF and PUE for SB19 and SB24 genotypes in both Trials at ( $p \leq 0.05)$. The highest $N$ tissue content of between $1.73 \%$ and $9.10 \%$ was observed when integration of $R$ and $P$ were applied at the rate of $200 \mathrm{~g}$ and $30 \mathrm{~kg}$ for SB19 and $S B 24$ in both Trials. While $R$ and $P$ at the rate of $200 \mathrm{~g}$ and $30 \mathrm{~kg}$ per ha showed the highest $P$ content of between 849.6 ppm and 955.0 ppm in both Trials. The highest SEF recorded was $207 \%$ and $261 \%$, and $201 \%$ and $227 \%$ in Trials I and II, respectively. The PUE was highest when $R$ and $P$ was applied at the rate of $200 \mathrm{~g}$ and $30 \mathrm{~kg}$ per ha for SB19 and SB24 soybean in both Trials. Integration of $R$ and $P$ at the rate of $200 \mathrm{~g}$ and $30 \mathrm{~kg} \mathrm{ha}^{-1}$ and adoption of either SB19 or SB24 showed a potential in enhancing soybean cultivation.
\end{abstract}

Keywords - Genotypes, phosphorus use efficiency, symbiotic, Tissue content.

\section{INTRODUCTION}

Soybean (Glycine max) is a crop that is cultivated as a source of livestock feed, human food and soil fertility improvement. It is the world's largest source of protein feed, the second largest source of vegetable oil and the fourth leading crop produced globally [2][3]. Biological nitrogen fixation is crucial and efficient process in improving soil fertility [4]. Application of phosphorus in soybean cultivation enhanced biological nitrogen fixation BNF in soybean-rhizobium interaction [5] increasing nitrogen content in plant tissues [6]. Integration of rhizobium and phosphorus was reported to have improved uptake of $\mathrm{N}$ and $\mathrm{P}$ in soybean [7]. Elsewhere, intercrop of Soybean/maize resulted to a higher nitrogen content in maize grain, indicating enhanced nitrogen uptake [8]. Phosphorus content in grain and straw was influenced by $\mathrm{R}$ and $\mathrm{P}$ application [9]. Plant nitrogen concentration in response to increased soil phosphorus supply was observed, with 
phosphorus content in grain and straw being highest in integration of $\mathrm{R}$ and $\mathrm{P}$ [10]. Phosphorus and nitrogen play specific roles in symbiotic $\mathrm{N}_{2}$-fixation efficiency through their effects on nodulation and $\mathrm{N}_{2}$-fixation process [11]. High yields with subsequent profits, are related to symbiotic efficiency (SEF) of soybean with N-fixing bacteria [12]. Nitrogen fixation is very sensitive to $\mathrm{P}$ deficiency due to reduced nodule mass and decreased ureide production [7]. Symbiotic N-fixation has a high $\mathrm{P}$ demand for energy provision [13][14].

Nitrogen fixation varied among rhizobia isolates with SEF ranging between 27 and $112 \%$ when beans were inoculated with R [15] Isolates from beans had higher SEF compared to the commercial inoculants [15]. Koskey et al. [16] used plant shoot dry weight to estimate SEF which ranged between 86.7 - $123.72 \%$ in common beans. In seed potato tuber production, phosphorus use efficiency PUE increased from $0 \mathrm{~kg} / \mathrm{kg}$ observed with $0 \mathrm{~kg} \mathrm{P}$ per ha and $0 \mathrm{~kg} \mathrm{~N}$ per ha to a range of $75.9 \mathrm{~kg} / \mathrm{kg}$ to $186.6 \mathrm{~kg} / \mathrm{kg}$ when integration of $\mathrm{P}$ and $\mathrm{N}$ was used [17].

\section{MATERIALS AND METHODS}

The experiment was conducted at Chuka University farm, Meru South Sub-County in two cultivations (Trial I and II) in 2018. Chuka University lies at an altitude of $1399 \mathrm{~m}$ above sea level, at latitude of $0^{\circ} 20^{\prime} 0^{\prime \prime} \mathrm{S}$ and longitude of $37^{\circ} 39^{\prime} 0^{\prime \prime} \mathrm{E}$ (Fig. 1). Temperature range of $20.97{ }^{\circ} \mathrm{C}-27.25$ ${ }^{\circ} \mathrm{C}$, rainfall of $1178 \mathrm{~mm}$, and nitisol type of soils. Major crops in the area are; Phaseolus vulgaris, Vigna unguiculate, Cajanus cajan, Glycine max, Sorghum spp, Musa spp, Mangifera indica, Coffea arabica and Camellia sinensis [18].

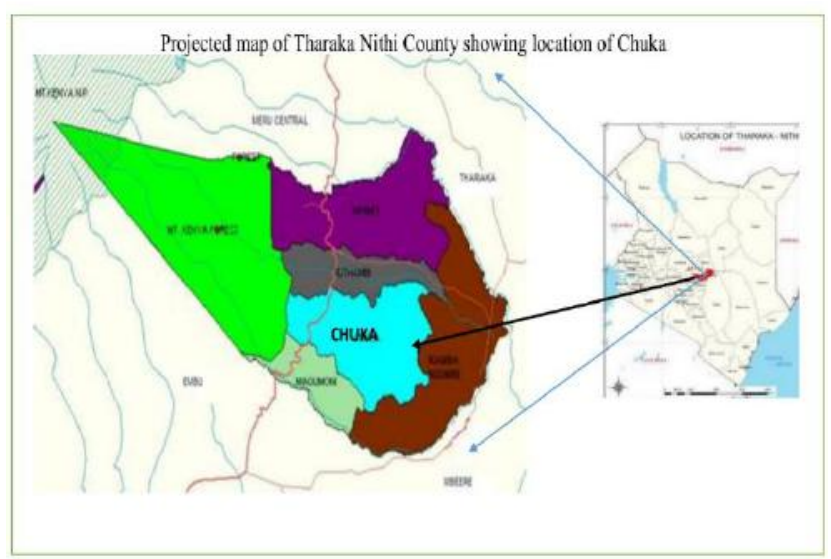

Fig.1: Location of Chuka in Tharaka Nithi County in Kenya

\section{EXPERIMENTAL DESIGN}

The experiment was laid out in a randomized complete block design in a split-split plot arrangement with each treatment replicated thrice. Treatments included; three rates of $\mathrm{P}\left(0,20\right.$ and $\left.30 \mathrm{Kg}^{-} \mathrm{ha}^{-1}\right)$, and three rates of $\mathrm{R}(0,100$ and $200 \mathrm{~g} \mathrm{ha}^{-1}$ ) either applied alone or integrated and two soybean genotypes (SB19 and SB24). The triple superphosphate (0:46:0) was used as the source of phosphorus. The SB19 and SB24 genotypes were assigned the main plot, $\mathrm{P}$ rates the sub-plot and $\mathrm{R}$ rates to subsubplots. The size of experimental plot was $1.5 \times 1.3 \mathrm{~m}$ with $1 \mathrm{~m}$ path between main plots and $0.5 \mathrm{~m}$ between subplots and sub-subplots.

\section{A. Soil Sampling and Analysis}

The soil was sampled across and diagonally in each site at a depth of $25 \mathrm{~cm}$ using a soil auger. A kilogram of a homogeneous composite soil sample from each site was packed independently into sterile bags for analysis. Soil analysis was done at Kenya Agricultural Research and Livestock Organization (KALRO) - Embu.

B. Planting Materials, Planting and Crop Management Certified soybean seeds and inoculant were obtained from KALRO-Kakamega and MEA Limited-Nakuru respectively. The inoculation was done in Plant Science Laboratory of Chuka University. Where soybean seeds were moistened with $4 \%$ Gum Arabica solution in a basin and the inoculant was added at the rates of $10 \mathrm{~g}$ per $\mathrm{Kg}$ and $20 \mathrm{~g}$ per $\mathrm{Kg}$ of soybean seeds. The mixture was stirred until even coating was attained. The seeds were then spread on flat plywood under a shade and allowed to air dry for 30 minutes. Inoculated seeds were sown early in the morning to avoid its exposure to direct sun rays that could affect the efficacy of the inoculant.

A basal application of phosphorus at the rate of $0 \mathrm{Kg}, 20$ $\mathrm{Kg}$, and $30 \mathrm{Kg} \mathrm{P}$ per ha which was equivalent to $0 \mathrm{~g}, 3.6 \mathrm{~g}$, and $5.4 \mathrm{~g}$ per plot was done during planting to the assigned plots. Two seeds were sown at inter and intra row spacing of $0.5 \mathrm{~m}$ and $0.1 \mathrm{~m}$ respectively in a plot measuring $1.2 \mathrm{~m} \mathrm{x}$ $1.5 \mathrm{~m}$. Seedlings were thinned to one per hill one week after emergence giving a plant population of 200,000 plants per ha or 39 plants per plot. All cultural practices recommended for soybean cultivation were done equally to all the plots.

\section{Data Collection}

1) Integration Effect of Different Rates of Rhizobium and Phosphorus on Shoot and Grain Nitrogen and Phosphorus Content

Twenty grams of shoot and grain from experimental plants were randomly taken from every plot, placed in khaki papers and dried in the oven at $60{ }^{\circ} \mathrm{C}$ for 72 hours. Dry shoot and grain samples were ground into powder using a blender. The powder was then sieved using a laboratory test sieve and packed in khaki paper bags ready for laboratory 
analysis. The plant shoots and grain powder were analyzed for nitrogen $(\% \mathrm{~N})$ and $\mathrm{P}(\mathrm{ppm})$ content using Kjeldahl according to Bremner [19].

\section{a) Integration Effect of Different Rates of Rhizobium} and Phosphorus on Rhizobium Use Efficiency

The plant shoot dry weight (SDW) was used to estimate the symbiotic nitrogen-fixing efficiency (SEF) of the commercial R. Symbiotic efficiency in this study was determined according to Koskey et al. [16], using the formula below:

$$
S E F=100 \times\left[\frac{(S D W \text { of inoculated }(\mathrm{Kg})]}{S D W \text { of non inoculated }(\mathrm{Kg})}\right]
$$

\section{b) Integration Effect of Different Rates of Rhizobium and Phosphorus on Phosphorus Use Efficiency}

The phosphorus use efficiency (PUE) was computed according to Belete et al. [20] using the formula below:

PUE

$=\left[\frac{(\text { Seed yield }(\mathrm{kg}) \text { of plots with Fert. }- \text { yield }(\mathrm{kg}) \text { control }}{\text { Quantity of phosphorus }(P) \text { applied in } \mathrm{kg} \text { per plot }}\right]$

\section{Data analysis}

The data collected was subjected to analysis of variance using the statistical scientific analysis system for windows V8 1999-2001 by SAS Institute Inc., Cary, NC, USA and significantly different means separated using Tukey test at $p \leq 0.05$.

\section{RESULTS}

\section{1) Integration Effect of Different Rates of Rhizobium and Phosphorus on Shoot and Grain Nitrogen Content}

There were no significant difference in shoot and grain $\mathrm{N}$ content between genotype SB19 and SB24 within and between Trial I and II $(p \leq 0.05)$. However, there were significant respond of the integration of $\mathrm{R}$ and $\mathrm{P}$ in shoot and grain N content within genotypes SB19 and SB24 at $(p \leq 0.05)$ in both Trials. Rhizobia application at the highest rate of $200 \mathrm{~g}$ per ha, increased the shoot $\mathrm{N}$ content from the control to $1.4 \%$ and $1.03 \%$, and $1.46 \%$ and $1.09 \%$ for SB19 and SB24 genotypes in Trials I and II, respectively (Table 1). Application of $P$ at the highest rate of $30 \mathrm{Kg}$ per ha, shoot $\mathrm{N}$ content increased from the control treatment to $0.94 \%$ and $0.83 \%$, and $0.96 \%$ and $0.86 \%$ for SB19 and SB24 genotypes in both Trial I and II, respectively (Table 1). While, highest integration of $\mathrm{R}$ and $\mathrm{P}$ at the rate of $200 \mathrm{~g}$ and $30 \mathrm{Kg}$ per ha, increased shoot $\mathrm{N}$ content to $2.98 \%$ and $1.73 \%$, and $3.09 \%$ and $1.73 \%$ for SB19 and SB24 genotypes in both Trial I and II, respectively (Table 1).
Integration of $\mathrm{R}$ and $\mathrm{P}$ significantly increased grain $\mathrm{N}$ content for SB19 and SB24 genotypes in both Trial I and II whether applied alone or integrated. Rhizobia at the highest rate of $200 \mathrm{~g}$ per ha, increased grain $\mathrm{N}$ content to $5.97 \%$ and $5.11 \%$, and $6.02 \%$ and $5.07 \%$ for SB19 and SB24 genotypes in both Trial I and II, respectively. Compared to control, highest integration of $\mathrm{R}$ and $\mathrm{P}$ at the rate of $200 \mathrm{~g}$ and $30 \mathrm{Kg}$ per ha, increased grain $\mathrm{N}$ content by $3.81 \%$ and $2.11 \%$, and $3.53 \%$ and $1.93 \%$ for SB19 and SB24 genotypes in both Trial, respectively (Table 1).

Table 1: Effect of Rhizobia and Phosphorus on Soybean Shoot and Grain N Content.

\begin{tabular}{llll|ll}
\hline Variety & \multicolumn{2}{c|}{ Trial 1 } & \multicolumn{2}{c}{ Trial 2 } \\
& Trt & Shoot & Grain N & Shoot & Grain \\
& & N $(\%)$ & $(\%)$ & $(\mathrm{N} \%)$ & $\mathrm{N}(\%)$ \\
\hline SB19 & T1 & $0.81^{\mathrm{g} *}$ & $5.12^{\mathrm{g}}$ & $0.7^{\mathrm{g}}$ & $4.4^{\mathrm{f}}$ \\
& T2 & $0.88^{\mathrm{gf}}$ & $5.54^{\mathrm{f}}$ & $0.8^{\mathrm{fg}}$ & $4.5^{\mathrm{f}}$ \\
& T3 & $0.94^{\mathrm{f}}$ & $5.69^{\mathrm{fe}}$ & $0.83^{\mathrm{fe}}$ & $4.73^{\mathrm{e}}$ \\
& T4 & $0.98^{\mathrm{f}}$ & $5.8^{\mathrm{e}}$ & $0.92^{\mathrm{e}}$ & $4.83^{\mathrm{e}}$ \\
& T5 & $1.53^{\mathrm{d}}$ & $6.8^{\mathrm{c}}$ & $1.06^{\mathrm{d}}$ & $5.20^{\mathrm{c}}$ \\
& T6 & $2.2^{\mathrm{b}}$ & $7.69^{\mathrm{b}}$ & $1.6^{\mathrm{b}}$ & $5.41^{\mathrm{b}}$ \\
& T7 & $1.4^{\mathrm{e}}$ & $5.97^{\mathrm{d}}$ & $1.03^{\mathrm{d}}$ & $5.11^{\mathrm{d}}$ \\
& T8 & $2.15^{\mathrm{c}}$ & $6.82^{\mathrm{c}}$ & $1.44^{\mathrm{c}}$ & $5.31^{\mathrm{b}}$ \\
& T9 & $2.98^{\mathrm{a}}$ & $8.93^{\mathrm{a}}$ & $1.73^{\mathrm{a}}$ & $6.51^{\mathrm{a}}$ \\
& T1 & $0.78^{\mathrm{g}}$ & $5.57^{\mathrm{g}}$ & $0.71^{\mathrm{g}}$ & $4.64^{\mathrm{f}}$ \\
& T2 & $0.92^{\mathrm{gf}}$ & $5.62^{\mathrm{f}}$ & $0.81^{\mathrm{fg}}$ & $4.62^{\mathrm{f}}$ \\
& T3 & $0.96^{\mathrm{f}}$ & $5.83^{\mathrm{fe}}$ & $0.86^{\mathrm{fe}}$ & $4.84^{\mathrm{e}}$ \\
& T4 & $0.98^{\mathrm{f}}$ & $5.80^{\mathrm{e}}$ & $0.96^{\mathrm{e}}$ & $4.88^{\mathrm{e}}$ \\
& T5 & $1.63^{\mathrm{d}}$ & $6.80^{\mathrm{c}}$ & $1.07^{\mathrm{d}}$ & $5.29^{\mathrm{c}}$ \\
& T6 & $2.46^{\mathrm{b}}$ & $7.74^{\mathrm{b}}$ & $1.6^{\mathrm{b}}$ & $5.61^{\mathrm{b}}$ \\
& T7 & $1.46^{\mathrm{e}}$ & $6.02^{\mathrm{d}}$ & $1.09^{\mathrm{d}}$ & $5.07^{\mathrm{d}}$ \\
& T8 & $2.10^{\mathrm{c}}$ & $6.98^{\mathrm{c}}$ & $1.5^{\mathrm{c}}$ & $5.50^{\mathrm{b}}$ \\
& T9 & $3.09^{\mathrm{a}}$ & $9.10^{\mathrm{a}}$ & $1.73^{\mathrm{a}}$ & $6.57^{\mathrm{a}}$ \\
\hline
\end{tabular}

*Means with the same letter along the column for the same variety are not significantly different at $p \leq 0.05$; MSD=Mean Significant Difference; Treatments: $T 1=$ Control $(0 \mathrm{~g} \mathrm{R}$ and $0 \mathrm{Kg} P$ per ha); $\mathrm{T} 2$ and $\mathrm{T3}=20 \mathrm{Kg}$ and $30 \mathrm{Kg} P$ per ha respectively; $T 4$ and $T 7=100 \mathrm{~g} R$ and $200 \mathrm{~g}$ $R$ per ha respectively; T5 $=100 \mathrm{~g} R$ and $20 \mathrm{Kg} P$ per ha, T6=100 $\mathrm{g} R$ and $30 \mathrm{Kg} P$ per ha; T8=200 $\mathrm{g} R$ and $20 \mathrm{Kg} \mathrm{P}$ per ha and $T 9=200 \mathrm{~g} R$ and $30 \mathrm{Kg} P$ per ha; $R=$ Rhizobia; $P=$ Phosphorus.

Integration Effect of Different Rates of Rhizobium and Phosphorus on Shoot and Grain Phosphorus Content There was no significant difference in shoot and grain $\mathrm{P}$ content between genotype SB19 and SB24 within and between the two Trials $(p \leq 0.05)$. However, there were 
significant effect of the integration of $\mathrm{R}$ and $\mathrm{P}$ in shoot and grain P content within genotypes SB19 and SB24 at $(p \leq 0.05)$ in Trials I and II. Rhizobia application increased shoot P content in SB19 and SB24 genotypes in both Trial $\mathrm{I}$ and II. Application of $\mathrm{R}$ at the rate of $100 \mathrm{~g}$ per ha, significantly increased the Shoot $\mathrm{P}$ content from $253.1 \mathrm{ppm}$ and $248.2 \mathrm{ppm}$, and $256.9 \mathrm{ppm}$ and $251.8 \mathrm{ppm}$ observed with the control treatment to $334.3 \mathrm{ppm}$ and $328.4 \mathrm{ppm}$, and $337.4 \mathrm{ppm}$ and $332.1 \mathrm{ppm}$ for SB19 and SB24 genotypes in both Trial I and II, respectively (Table 1).

Application of $\mathrm{P}$ at the highest rate of $30 \mathrm{Kg}$ per ha increased the Shoot $\mathrm{P}$ content from control treatment to 326.1 and $320.6 \mathrm{ppm}$, and 333.6 and $327.8 \mathrm{ppm}$ for SB19 and SB24 genotypes in Trial I and II, respectively (Table 2). While, integration of R and P at the highest rate of $200 \mathrm{~g}$ and $30 \mathrm{Kg}$ per ha, increased shoot $\mathrm{P}$ content to $849.6 \mathrm{ppm}$ and $906 \mathrm{ppm}$, and $849.6 \mathrm{ppm}$ and $913.8 \mathrm{ppm}$ for SB19 and SB24 genotypes in both Trial I and II, respectively (Table 2). Rhizobia application increased grain P content in SB19 and SB24 genotypes in both Trial I and II. For instance R application at the rate of $100 \mathrm{~g}$ per ha, significantly increased the grain $\mathrm{P}$ content from the control treatment to $509.9 \mathrm{ppm}$ and $519.6 \mathrm{ppm}$, and $514.1 \mathrm{ppm}$ and $524.5 \mathrm{ppm}$ for SB19 and SB24 genotypes in both Trial I and II, respectively. Compared to control, application of $\mathrm{R}$ at the rate of $200 \mathrm{~g}$ per ha significantly increased the grain $\mathrm{P}$ content from the control treatment to $430.1 \mathrm{ppm}$ and 529.6 ppm and 434.2 and $534.6 \mathrm{ppm}$ for SB19 and SB24 genotypes in both Trial I and II, respectively (Table 2). Application of $\mathrm{P}$ at the highest rate of $30 \mathrm{Kg}$ per ha, increased grain $\mathrm{P}$ content from the control treatment to $340.6 \mathrm{ppm}$ and $350.8 \mathrm{ppm}$, and $346.4 \mathrm{ppm}$ and $356.4 \mathrm{ppm}$ for SB19 and SB24 genotypes in Trial I and II, respectively (Table 2). Further, integration of $\mathrm{R}$ and $\mathrm{P}$ at the highest rate of $200 \mathrm{~g}$ and $30 \mathrm{Kg}$ per ha, significantly increased grain $\mathrm{P}$ content to $852.4 \mathrm{ppm}$ and $950 \mathrm{ppm}$, and $853.3 \mathrm{ppm}$ and 955 ppm for SB19 and SB24 genotypes in both Trials, respectively (Table 2).
Table 2: Effect of Rhizobia and Phosphorus on Soybean Shoot and Grain P Content.

\begin{tabular}{|c|c|c|c|c|c|}
\hline \multirow{2}{*}{$\begin{array}{l}\text { Variet } \\
\mathrm{y}\end{array}$} & \multicolumn{3}{|c|}{ Trial 1} & \multicolumn{2}{|l|}{ Trial 2} \\
\hline & Trt & $\begin{array}{l}\text { Shoot P } \\
\text { (ppm) }\end{array}$ & $\begin{array}{l}\text { Grain P } \\
\text { (ppm) }\end{array}$ & $\begin{array}{l}\text { Shoot P } \\
(\mathrm{ppm})\end{array}$ & $\begin{array}{l}\text { Grain P } \\
\text { (ppm) }\end{array}$ \\
\hline \multirow{9}{*}{ SB19 } & $\mathrm{T} 1$ & $253.1^{\mathrm{h}^{*}}$ & $225.6^{i}$ & $248.2^{\mathrm{h}}$ & $235.6^{\mathrm{i}}$ \\
\hline & $\mathrm{T} 2$ & $290.2^{\mathrm{g}}$ & $323.3^{\mathrm{h}}$ & $285.0^{\mathrm{g}}$ & $333.3^{\mathrm{h}}$ \\
\hline & $\mathrm{T} 3$ & $326.1^{\mathrm{f}}$ & $340.6^{\mathrm{g}}$ & $320.6^{\mathrm{f}}$ & $350.8^{\mathrm{g}}$ \\
\hline & $\mathrm{T} 4$ & $334.3^{\mathrm{f}}$ & $509.9^{e}$ & $328.4^{\mathrm{f}}$ & $519.6^{\mathrm{f}}$ \\
\hline & T5 & $488.4^{\mathrm{d}}$ & $579.8^{c}$ & $497.9^{d}$ & $589.8^{\mathrm{d}}$ \\
\hline & T6 & $671.6^{\mathrm{b}}$ & $734.4^{\mathrm{b}}$ & $737.2^{\mathrm{b}}$ & $834.3^{b}$ \\
\hline & $\mathrm{T} 7$ & $361.7^{\mathrm{e}}$ & $430.1^{\mathrm{f}}$ & $385.4^{\mathrm{e}}$ & $529.6^{\mathrm{e}}$ \\
\hline & $\mathrm{T} 8$ & $542.0^{c}$ & $524.6^{\mathrm{d}}$ & $649.9^{c}$ & $624.6^{\mathrm{c}}$ \\
\hline & T9 & $849.6^{\mathrm{a}}$ & $852.4^{\mathrm{a}}$ & $906.0^{\mathrm{a}}$ & $950.0^{\mathrm{a}}$ \\
\hline \multirow[t]{9}{*}{ SB24 } & $\mathrm{T} 1$ & $256.9^{\mathrm{h}}$ & $241.7^{\mathrm{i}}$ & $251.8^{\mathrm{h}}$ & $240.6^{\mathrm{i}}$ \\
\hline & $\mathrm{T} 2$ & $294.0^{\mathrm{g}}$ & 328.4 & $289.0^{\mathrm{g}}$ & $338.4^{\mathrm{h}}$ \\
\hline & $\mathrm{T} 3$ & $333.6^{\mathrm{f}}$ & $346.4^{\mathrm{g}}$ & $327.8^{\mathrm{f}}$ & $356.4^{\mathrm{g}}$ \\
\hline & $\mathrm{T} 4$ & $337.4^{\mathrm{f}}$ & $514.1^{\mathrm{e}}$ & $332.1^{\mathrm{f}}$ & $524.56^{\mathrm{f}}$ \\
\hline & T5 & $490.4^{\mathrm{d}}$ & $584.4^{\mathrm{c}}$ & $510.6^{\mathrm{d}}$ & $594.7^{\mathrm{d}}$ \\
\hline & T6 & $672.2^{\mathrm{b}}$ & $739.4^{\mathrm{b}}$ & $738.4^{\mathrm{b}}$ & $839.3^{\mathrm{b}}$ \\
\hline & $\mathrm{T} 7$ & $366.0^{\mathrm{e}}$ & 434.2 & $383.0^{\mathrm{e}}$ & $534.6^{\mathrm{e}}$ \\
\hline & $\mathrm{T} 8$ & $535.7^{\mathrm{c}}$ & $529.7^{\mathrm{d}}$ & $660.2^{c}$ & $629.7^{\mathrm{c}}$ \\
\hline & T9 & $849.6^{\mathrm{a}}$ & $853.3^{\mathrm{a}}$ & $913.8^{\mathrm{a}}$ & $955.0^{\mathrm{a}}$ \\
\hline MSD & & 9.7 & 0.19 & 6.73 & 0.14 \\
\hline C.V. & & 2.01 & 1.8 & 1.31 & 0.85 \\
\hline
\end{tabular}

*Means with the same letter along the column for the same variety are not significantly different at $(p \leq 0.05)$; MSD=Mean Significant Difference; Treatments: $T 1=$ Control $(0 \mathrm{~g} \mathrm{R}$ and $0 \mathrm{Kg} \mathrm{P} \mathrm{per} \mathrm{ha);} \mathrm{T2} \mathrm{and} \mathrm{T3=20} \mathrm{Kg} \mathrm{and}$ $30 \mathrm{Kg} P$ per ha respectively; $T 4$ and $T 7=100 \mathrm{~g} R$ and $200 \mathrm{~g}$ $R$ per ha respectively; $T 5=100 \mathrm{~g} R$ and $20 \mathrm{Kg} P$ per ha, $T 6=100 \mathrm{~g} \mathrm{R}$ and $30 \mathrm{Kg} \mathrm{P}$ per ha; T8=200 $\mathrm{g} \mathrm{R}$ and $20 \mathrm{Kg} \mathrm{P}$ per ha and $T 9=200 \mathrm{~g} R$ and $30 \mathrm{Kg} P$ per ha; $R=$ Rhizobia; $P=$ Phosphorus.

\section{Integration Effect of Different Rates of Rhizobium and Phosphorus on Symbiotic Efficiency}

There was no significant difference in symbiotic efficiency between genotype SB19 and SB24 within and between Trials I and II $(p \leq 0.05)$. However, there was significant influence of the integration of $\mathrm{R}$ and $\mathrm{P}$ in symbiotic efficiency (SEF) within genotypes SB19 and SB24 at $(p \leq 0.05)$ in Trials I and I. For instance, application of $\mathrm{R}$ at the rate of $100 \mathrm{~g}$, increased SEF from $101 \%$ and $107 \%$, and $101 \%$ and $100 \%$ observed with the control treatment to $129 \%$ and $165 \%$, and $114 \%$ and $116 \%$ for SB19 and SB24 genotypes in Trial I and II, respectively (Table 3 ). When P was applied at the highest rate of $30 \mathrm{Kg}$ per ha, SEF increased from the control treatment to $135 \%$ and $157 \%$, and $126 \%$ and $131 \%$ (Table 3). Compared to control 
integration of $\mathrm{R}$ and $\mathrm{P}$ at the highest rate of $200 \mathrm{~g}$ and 30 $\mathrm{Kg}$ per ha, increased SEF by $106 \%$ and $154 \%$, and 101 and
$127 \%$ for SB19 and SB24 genotypes in Trial I and II, respectively (Table 2).

Table 3: Effect of Rhizobia and Phosphorus on Symbiotic Efficiency (\%), Phosphorus (Kg/Kg) and Rhizobium (Kg/Kg)

\begin{tabular}{|c|c|c|c|c|c|}
\hline \multirow[t]{2}{*}{ Variety } & & & Trial 1 & & Trial II \\
\hline & Trt & SEF (\%) & $\begin{array}{l}\text { PUE } \\
(\mathrm{Kg} / \mathrm{Kg})\end{array}$ & SEF (\%) & PUE $(\mathrm{Kg} / \mathrm{Kg})$ \\
\hline \multirow[t]{9}{*}{ SB19 } & $\mathrm{T} 1$ & $101^{\mathrm{d}^{*}}$ & $0^{\mathrm{d}}$ & $107^{\mathrm{d}}$ & $0^{\mathrm{d}}$ \\
\hline & $\mathrm{T} 2$ & $108^{\mathrm{d}}$ & $4.65^{\mathrm{c}}$ & $119^{d}$ & $4.8^{\mathrm{c}}$ \\
\hline & $\mathrm{T} 3$ & $135^{\mathrm{cd}}$ & $3.9^{\mathrm{c}}$ & $157^{\mathrm{cd}}$ & $3.9^{\mathrm{c}}$ \\
\hline & $\mathrm{T} 4$ & $129^{\mathrm{cd}}$ & $0^{\mathrm{d}}$ & $165^{\mathrm{cd}}$ & $0^{\mathrm{d}}$ \\
\hline & T5 & $153^{\mathrm{bc}}$ & $8.15^{\mathrm{a}}$ & $182^{\mathrm{bc}}$ & $8.15^{b}$ \\
\hline & T6 & $176^{\mathrm{ab}}$ & $6.49^{b}$ & $149^{\mathrm{bc}}$ & $3.78^{c}$ \\
\hline & $\mathrm{T} 7$ & $130^{\mathrm{cd}}$ & $0^{\mathrm{d}}$ & $152^{\mathrm{cd}}$ & $0^{\mathrm{d}}$ \\
\hline & $\mathrm{T} 8$ & $167^{\mathrm{ab}}$ & $8.6^{\mathrm{a}}$ & $200^{\mathrm{ab}}$ & $8.96^{\mathrm{a}}$ \\
\hline & T9 & $207^{a}$ & $6.9^{\mathrm{a}}$ & $261^{\mathrm{a}}$ & $8.75^{\mathrm{a}}$ \\
\hline \multirow[t]{9}{*}{ SB24 } & $\mathrm{T} 1$ & $101^{\mathrm{d}}$ & $0^{\mathrm{d}}$ & $100^{\mathrm{d}}$ & $0^{\mathrm{d}}$ \\
\hline & $\mathrm{T} 2$ & $103^{d}$ & $4.2^{\mathrm{c}}$ & $104^{\mathrm{d}}$ & $4.3^{\mathrm{b}}$ \\
\hline & $\mathrm{T} 3$ & $126^{\mathrm{cd}}$ & $3.6^{\mathrm{c}}$ & $131^{\mathrm{cd}}$ & $3.6^{\mathrm{c}}$ \\
\hline & $\mathrm{T} 4$ & $114^{\mathrm{cd}}$ & $0^{\mathrm{d}}$ & $116^{\mathrm{cd}}$ & $0^{\mathrm{d}}$ \\
\hline & T5 & $145^{\mathrm{bc}}$ & $7.8^{\mathrm{a}}$ & $155^{\mathrm{bc}}$ & $3.8^{\mathrm{c}}$ \\
\hline & T6 & $187^{\mathrm{ab}}$ & $6.6^{\mathrm{bc}}$ & $209^{b c}$ & $4.2^{\mathrm{b}}$ \\
\hline & $\mathrm{T} 7$ & $119^{\mathrm{cd}}$ & $0^{\mathrm{d}}$ & $122^{\mathrm{cd}}$ & $0^{\mathrm{d}}$ \\
\hline & $\mathrm{T} 8$ & $179^{a b}$ & $8.9^{a}$ & $199^{a b}$ & $9^{a}$ \\
\hline & T9 & $201^{\mathrm{a}}$ & $9.4^{\mathrm{a}}$ & $227^{\mathrm{a}}$ & $9.5^{\mathrm{a}}$ \\
\hline MSD & & 31 & 1.3 & 46 & 1.4 \\
\hline $\mathrm{CV}(\%)$ & & 25 & 58 & 31 & 59 \\
\hline
\end{tabular}

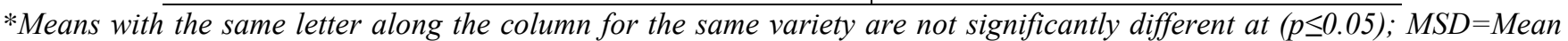
Significant Difference; Treatments: $T 1=$ Control $(0 \mathrm{~g} R$ and $0 \mathrm{Kg} P$ per ha); $T 2$ and T3=20 Kg and $30 \mathrm{Kg} P$ per ha respectively; $T 4$ and $T 7=100 \mathrm{~g} R$ and $200 \mathrm{~g} R$ per ha respectively; T5=100 $\mathrm{g} R$ and $20 \mathrm{Kg} P$ per ha, T6=100 $\mathrm{g} R$ and $30 \mathrm{Kg} P$ per ha; T8 $=200 \mathrm{~g} \mathrm{R}$ and $20 \mathrm{Kg} \mathrm{P}$ per ha and T9 =200 $\mathrm{g} R$ and $30 \mathrm{Kg} P$ per ha; PUE=Phosphorus Use Efficiency; SEF=Symbiosis efficiency

\section{Integration Effect of Different Rates of $R$ and $P$ on Phosphorus Use Efficiency}

There were no significant difference in phosphorus use efficiency (PUE) between genotype SB19 and SB24 within and between Trials I and II $(p \leq 0.05)$. However, there were significant respond of the integration of $\mathrm{R}$ and $\mathrm{P}$ in PUE within genotypes SB19 and SB24 at $(p \leq 0.05)$ in Trials I and II. When $\mathrm{P}$ was applied at the rate of $20 \mathrm{Kg}$ per ha, the soybean grain yield obtained increased to $4.65 \mathrm{Kg} / \mathrm{Kg}$ and $4.8 \mathrm{Kg} / \mathrm{Kg}$, and $4.2 \mathrm{Kg} / \mathrm{Kg}$ and $4.28 \mathrm{Kg} / \mathrm{Kg}$ for SB19 and SB24 soybean genotypes in Trial I and II, respectively (Table 3). Furthermore, when $\mathrm{P}$ was applied at the rate of $30 \mathrm{Kg}$ per ha the soybean grain yields increased from the control treatment to $3.93 \mathrm{Kg} / \mathrm{Kg}$ and $3.9 \mathrm{Kg} / \mathrm{Kg}$, and 3.58 $\mathrm{Kg} / \mathrm{Kg}$ and $3.6 \mathrm{Kg} / \mathrm{Kg}$ for SB19 and SB24 genotypes in Trial I and II, respectively. Integration of $\mathrm{R}$ and $\mathrm{P}$ at the highest rate of $200 \mathrm{~g}$ and $30 \mathrm{Kg}$ per ha increased grain yield from the control treatment to $6.9 \mathrm{Kg} / \mathrm{Kg}$ and $8.75 \mathrm{Kg} / \mathrm{Kg}$, and $9.37 \mathrm{Kg} / \mathrm{Kg}$ and $9.48 \mathrm{Kg} / \mathrm{Kg}$ for SB19 and SB24 genotypes in Trial I and II, respectively (Table 3).

\section{DISCUSSIONS}

There was significant increase of shoot and grain $\mathrm{N}$ uptake, these probably, could be associated with $\mathrm{R}$ and $\mathrm{P}$. Which enhanced $\mathrm{N}$ fixation, root length and root mass resulting to absorption of mineral nutrients from the soil, particularly available N. Similarly, significant increase in root nodules due to integration of $\mathrm{R}$ and $\mathrm{P}$, probably, increased $\mathrm{N}_{2}$ fixation. This led to increase in $\mathrm{N}$ uptake which is in agreement with Bargaz et al. [21] who observed that, $\mathrm{P}$ plays a vital role in physiological and developmental process in plants. Similarly, significant increase in root nodulation due to integration of Rand $\mathrm{P}$ increased $\mathrm{N}_{2}$ fixation that led to increase in $\mathrm{N}$ uptake by shoot and grain of soybean. 
Higher $\mathrm{P}$ content in shoot and grain was attributed to the root length of soybean. A long root system might have created a greater root-soil contact which increased $\mathrm{P}$ uptake hence high $\mathrm{P}$ content in shoot and grain. These findings are in agreement with Mathenge [11] who observed that a larger root system enhanced by $\mathrm{P}$ provided greater root-soil contact hence higher uptake. Furthermore, high shoot and grain $\mathrm{P}$ content can be attributed to the presence of $\mathrm{R}$ applied which enhanced the solubilization of the $\mathrm{P}$ in the soil increasing available $\mathrm{P}$ for the uptake. This is in agreement with Adjei-Nsiah et al. [1] who observed that rhizobium has the ability to solubilize $\mathrm{P}$ increasing $\mathrm{P}$ concentration in the soil. This concurs with Abbasi et al. [22] who reported that soybean grain/straw P uptake was increased with increased integration of $\mathrm{P}$ and $\mathrm{R}$.

High SEF observed in control treatment in both Trails, probably, suggest that native $\mathrm{R}$ were active and effective, which consequently increased SDW. Further, the good performance of control, could be associated with native strain adaptation to the ecological conditions of the study area. These results are in agreement with the findings by Kawaka et al. [23] who reported SEF ranging between 67 and $170 \%$ when common beans were inoculated with native rhizobia.

High performance of commercial R probably, could be associated with the commercial strains being more adapted to the study area compared to the native strains, leading to higher performance in SEF. This is contrary to Mungai and Karubiu [24] who observed native rhizobia isolated from common beans having higher SEF compared to commercial inoculants. Integration of $\mathrm{R}$ and $\mathrm{P}$ had the highest SEF, probably, this was associated with enhanced energy provision by $\mathrm{P}$ which improved the performance. This concurs with the findings by Bargaz et al.[21] who reported BNF having a high $\mathrm{P}$ energy demand.

Low PUE where $\mathrm{P}$ was applied alone in the present study, probably, may be associated with $\mathrm{P}$ fixation in the soil (beyond scope of this study) making $\mathrm{P}$ less available to the plants. This concurs with findings by Fageria and Barbosa [25] and Singh et al.[26] who observed higher P fixation decreasing PUE in lentil and rice enterprises, respectively. Overall, the present study observed low soybean grain produced for every $\mathrm{Kg}$ of $\mathrm{P}$ applied for soybean genotype SB19 and SB24 in trial I and II, respectively. This economic production was below findings by Abbasi et al. [22] who reported higher soybean grain yield produced with each $\mathrm{Kg}$ of phosphorus applied.

\section{CONCLUSIONS AND RECOMMENDATIONS}

This study demonstrated that integration of $\mathrm{R}$ and $\mathrm{P}$ at the rate of $200 \mathrm{~g}$ and $30 \mathrm{~kg}$ per ha was the optimum rate of application compared to other treatment levels in soybean performance. It was observed that symbiotic and phosphorus use efficiency was influenced by the $\mathrm{R}$ and $\mathrm{P}$ for SB19 and SB24 soybean genotypes. The two genotypes, SB19 and SB24 performed equally well. Farmers can adopt integration of $\mathrm{R}$ and $\mathrm{P}$ at the rate of $200 \mathrm{~g}$ and $30 \mathrm{~kg}$ per ha and either of the genotypes for sustainable soybean cultivation. Further research by use of other sources of $\mathrm{P}$ such as phosphorus solubilizing bacteria to enhance symbiotic and phosphorus use efficiency is recommended.

\section{ACKNOWLEDGEMENT}

The authors acknowledge Chuka University for the provision of the Trial sites and laboratory space where research was done. Thanks to the entire family of the Department Plant Sciences for their moral support throughout the research period.

\section{REFERENCES}

[1] S. Adjei-Nsiah, J. Kumah, E. Owusu-Bennoah and F. Kanampiu, " Influence of $\mathrm{P}$ sources and rhizobium inoculation on growth and yield of soybean genotypes on Ferric Lixisols of Northern Guinea savanna zone of Ghana," Communication in Soil Science and Plant Analysis, pp. 1532-2416, 2019.

[2] L. Tani, T. Anh, H. James and A. Mark, " Major Factors Affecting Global Soybean and Products Trade Projections," Economic Research Service, 2016.

[3] H. M. Murithiab, F. Beedc, P. Tukamuhabwad, B. P. Thommab and M. H. Joosten, "Soybean production in eastern and southern Africa and threat of yield loss due to soybean rust caused by Phakopsora pachyrhizi. Plant Pathology," Plant Pathology, vol. 65, p. 176-188, 2016.

[4] G. C. diCenzo, M. Zamani, A. Checcucci, M. Fondi, J. S. Griffitts, T. M. Finan and A. Mengoni, "Multidisciplinary approaches for studying rhizobium-legume symbioses," Can. J. Microbiol., vol. 65, pp. 1-33, 2019.

[5] Q. H. Zhou, Q. T. Y. L. Chen and Y. Wang, "Light-induced ambient degradation of Few-layer black phosphorus: Mechanism and protection," Angewandte Chemie, vol. 128, pp. 11609-11613, 2016.

[6] K. Bashir, S. Ali and A. Umair, " Effect of different phosphorus levels on xylem sap components and their correlation with growth variables of mash bean," Sarhad J. Agric., vol. 27, pp. 1-6, 2011.

[7] R. J. Shish, K. Vinod, N. G. Mitra and S. Ompal, "Effect of Soybean (Glycine max) Seed Inoculation with Liquid and Carrier Based Rhizobium cultures and Phosphorus Levels on Productivity and Physico-Chemical Properties of Soil," Int. J. Curr. Microbiol. App. Sci, vol. 7, no. 6, pp. 1807-1814, 2018.

[8] B. Vanlauwe, J. Wendt, K. E. Giller, M. Corbeels, B. Gerard and C. Nolte, "A fourth principle is required to 
define conservation agriculture in sub-Saharan Africa: The appropriate use of fertilizer to enhance crop productivity," Field Crops Research, vol. 155, no. 10-13, 2014.

[9] A. T. Masresha, “ Effects of Rhizobium, Nitrogen and Phosphorus Fertilizers on Growth, Nodulation, Yield and Yield Attributes of Soybean at Pawe Northwestern Ethiopia. Retrieved November 16, 2017. World Scientific News: www.worldscientificnews.," 2017.

[10] R. Nasir, M. K. Abbasi and S. Hameed, "Variability in the growth and nodulation of soybean in response to elevation and soil properties in the Himalayan region of of KashmirPakistan," Pakistan Journal of Botany, vol. 49, no. 1, pp. 237-247, 2017.

[11] C. Mathenge, "Variability of soybean response to rhizobia inoculant, Vermicompost, and a legume-specific fertilizer blend in Siaya County of Kenya," Thesis, 2018.

[12] L. P. Barbosa, P. Costa, P. R. Ribeiro, M. Rufini, A. A. Guimarães and F. M. Moreira, "Efficiency and Genotypic Characterization of Variants of Bradyrhizobium spp. in Commercial Inoculants for Soybeans," Rev Bras Cienc Solo, vol. 15, pp. 1-15, 2017.

[13] E. V. Tairo and P. Ndakidemi, “ Macronutrients uptake in soybean as affected by Bradyrhizobium japonicum inoculation and phosphorus (P) supplements," Am. J. Plant Science, vol. 5, pp. 488-496, 2014.

[14] J. H. Makoi, R. S. Bambara and P. A. Ndakidemi, “ Rhizobium Inoculation and the Supply of Molybdenum and Lime Affect the Uptake of Macronutrients in Common Bean (P. vulgaris L.)," Plants. Aust. J. Crop Sci., vol. 7, no. 6, pp. 784-793, 2013.

[15] F. Kawaka, M. Dida, P. Opala, O. Ombori, J. Maingi, A. Amoding and J. Muoma, "Effect of nitrogen sources on the yield of common bean (Phaseolus vulgaris) in western Kenya. Journal of Plant Nutrition," Journal of Plant Nutrition, vol. 41, no. 13, pp. 1652-1661, 2018.

[16] G. Koskey, S. Mburu and E. Njeru, "Potential of Native Rhizobia in Enhancing Nitrogen Fixation and Yields of Climbing Beans (Phaseolus Vulgaris L.) in Contrasting Environments of Eastern Kenya," Frontiers in Plant Science, vol. 8, no. 443, pp. 1-2, 2017.

[17] G. K. Gathungu, A. N. Joseph and I. K. Dorcas, "Effects of Irrigation Water and Mineral Nutrients Application Rates on Tissue Contents and Use Efficiencies in Seed Potato Tuber Production," International Journal of Plant and Soil Science, vol. 9, no. 1153-1166, p. 3, 2014.

[18] F. O. Ogolla, M. M. Muraya and B. O. Onyango, "Incidence and Severity of Turcicum Leaf Blight Caused by Exserohilum turcicum (pass.) Leonard and Suggs) on Sorghum Populations in Different Regions of Tharaka Nithi County, Kenya," Journal of Scientific and Engineering Research, vol. 6, no. 1, pp. 104-111, 2019.

[19] J. M. Bremner, "Soil pH and Lime Requirement. Methods of Soil Analysis Part 3," Chemical Methods, vol. 3, 1996.
[20] F. Belete, N. Dechassa, A. Molla and T. Tana, "Effect of nitrogen fertilizer rates on grain yield and nitrogen uptake and use efficiency of bread wheat (Triticum aestivum L.) varieties on the Vertisols of central highlands of Ethiopia," Agriculture and Food Science, vol. 7, no. 78, pp. 1-12, 2018.

[21] A. Bargaz, K. Lyamlouli, M. Chtouki, Y. Zeroual and D. Dhiba, "Soil Microbial Resources for Improving Fertilizers Efficiency in an Integrated Plant Nutrient Management System," Front. Microbiol., vol. 9, p. 1606, 2018.

[22] M. K. Abbasi, M. Manzoor and M. M. Tahir, “ Efficiency of rhizobium inoculation and $\mathrm{P}$ fertilization in enhancing nodulation, seed yield, and phosphorus use efficiency by field grown soybean under hilly region of Rawalakot Azad Jammu and Kashmir," Journal of Plant Nutrition, vol. 33, no. 7, pp. 100-1102, 2010.

[23] F. Kawaka, M. M. Dida and P. A. Opala, "Genetic diversity of symbiotic bacteria nodulating common bean (Phaseolus vulgaris) in western Kenya," Sch. Res. Notices., vol. 14, no. 11, pp. 1-13, 2018

[24] N. W. Mungai and N. M. Karubiu, "Effectiveness of rhizobia isolates from Njoro soils (Kenya) and commercial inoculants in nodulation of common beans (Phaseolus vulgaris)," J. Agric. Sci. Technology, vol. 12, p. 47-59, 2011.

[25] N. K. Fageria and F. M. P. Barbosa, "Dry-matter and grain yield, nutrient uptake and phosphorus use-efficiency of low land rice as influenced by phosphorus fertilization," Communications in SoilScience and Plant Analysis, vol. 38, pp. 1289-1297, 2007.

[26] K. K. Singh, C. Srinivasarao and M. Ali, “ Root growth, nodulation, grain yield, and phosphorus use efficiency of lentil as influenced by phosphorus, irrigation, and inoculation," Communications in Soil Science and Plant Analysis, vol. 36, pp. 1919-1929, 2005.

[27] B. Singh, Y. Singh and G. Sekhon, "Fertilizer-N use efficiency and nitrate pollution of groundwater in developing countries," Journal of Contaminant Hydrology, vol. 20, pp. 167-184, 2006. 